\title{
Improving Civics Learning Achievement Through Giving Initial Assignments in State High Schools
}

\author{
Mustapa T \\ State High School 4 Polewali/IAI DDI Polewali Mandar, Indonesia \\ mustapatutu66@gmail.com
}

\begin{abstract}
This research is related to improving students' learning achievement by giving beginning tasks before the material is presented at citizen lesson at grade X SMA Negeri 4 Polewali academic year 2019-2020. The population of this research are the students of four classes, with 144 students. At the same time, the sample consists of two classes with 72 students. This sample divided into two groups, namely the control group and experiment one. The method of this research is an experiment by using t-test data analysis technique. This research shows that the student's learning achievement was taught by giving the Initial Assignments with the mean score 7.81 while the students' learning achievement without Initial Assignments 7.07. It means that the student's learning achievement by giving Initial Assignments is higher than the students' learning achievement without initial Assignments.
\end{abstract}

Keywords: Improvement, Initial Assignment, Learning Achievement

\begin{abstract}
Abstrak. Penelitian ini berkaitan dengan peningkatan prestasi belajar siswa dengan memberikan tugas awal sebelum materi disampaikan pada pelajaran warga kelas X SMA Negeri 4 Polewali tahun ajaran 2019-2020. Populasi dalam penelitian ini adalah siswa dari empat kelas yang berjumlah 144 siswa. Sedangkan sampel terdiri dari dua kelas dengan 72 siswa. Sampel ini dibagi menjadi dua kelompok, yaitu kelompok kontrol dan kelompok eksperimen. Metode penelitian ini adalah eksperimen dengan menggunakan teknik analisis data uji-t. Hasil penelitian menunjukkan bahwa prestasi belajar siswa diajar dengan pemberian Tugas Awal dengan nilai rata-rata 7,81 sedangkan prestasi belajar siswa tanpa Tugas Awal 7,07. Artinya prestasi belajar siswa dengan pemberian Tugas Awal lebih tinggi daripada prestasi belajar siswa tanpa Pemberian Tugas Awal.
\end{abstract}

Kata Kunci: Peningkatan, Tugas Awal, Prestasi Belajar 


\section{INTRODUCTION}

Citizenship Education subjects are considered boring subjects because material obtained from elementary, junior high school, high school, and even university levels. Not for students, it isn't easy to understand the theoretical Citizenship Education material. In a situation where a teacher in carrying out learning must use multiple methods so that the subject matter of Citizenship Education for students is presented in a form that is fun, not boring and has initial knowledge. A student who has never heard and read the material presented will have difficulty understanding the teacher's explanation because the student concerned does not know the subject matter being taught.

Teachers in carrying out their duties face many obstacles. In addition to the curriculum full of content, the evaluation system influences the way teachers deliver. The teacher uses various teaching, for example, the lecture method, question and answer, giving assignments. So far, the method of giving assignments that teachers usually do is to provide practice questions at home after the Citizenship Education lesson is finished at school. The Citizenship Education teacher did not realize this assignment, whether giving assignments after the learning process is complete can motivate students to learn, or on the contrary, they become afraid and avoid Citizenship Education lessons. To encourage students to be interested in
Citizenship Education subjects, a teacher must be very good at reading students' symptoms. Teachers can do so that students are motivated to learn Citizenship Education to generate interest in reading for students. Generating interest in reading for students can be done by giving assignments before the Civics Education material is taught. Reading textbooks before the teacher explains the material is effective for students. While the factors that cause the lack of motivation of students to read because of the lack of motivation from the teacher. Learning techniques that have been carried out in giving assignments are more directed to giving assignments after the material is taught. This is done because to deepen students' knowledge of the material that has been taught. This method is carried out since students are in elementary, junior high and continue in high school so that for students, it is very boring. Besides, giving assignments after the subject matter of Citizenship Education is taught limits students to be more creative because students are only limited to things that have been learned. On the other hand, giving assignments before the material is taught will motivate students to be creative and try their best to find solutions to the tasks assigned by the teacher. Students who get new things that have never been obtained in previous lessons will be interested and challenged to find answers from various sources in the form of books, resource persons, and even fellow students will discuss so that a 
cooperative learning atmosphere will be created. It is hoped that giving assignments before the Civics Education subject matter is taught will generate interest in reading for students while providing initial knowledge for students about the material to be taught. Thus, when the learning process takes place in the classroom, a harmonious, active, communicative teaching and learning process will be created. There will be interactions between teachers and students, between students and teachers and between students and students (multi-directional). This is because students are more prepared with the material to be taught. The problems of this research are:

1. How is the learning achievement of class $X$ students for the 2019-2020 school year who are taught by giving initial assignments on Citizenship Education subject at State high school 4 Polewali.

2. How is the learning achievement of class $X$ students in the 2019-2020 school year who are taught without giving initial assignments in the Citizenship Education subject at State high school 4 Polewali.

3. Is there a difference in the learning achievement of class $\mathrm{X}$ students in the 2019-2020 school year who are taught by giving initial assignments and the achievements of students who are taught without giving initial assignments in Citizenship Education subject at State high school 4 Polewali
This research is an effort to obtain information about effective teaching methods to generate effective student interest in reading in the end it can motivate students to improve their achievements, so it is hoped that this research can be helpful, among others (1) Can be beneficial information for Citizenship Education teachers especially in choosing effective teaching methods in improving student achievement. (2) Can be a reference for Citizenship Education teachers in choosing teaching methods to arouse students' interest in reading which in turn can motivate students to improve learning achievement.

According to Ivor K Davies (1991), learning strategies include deductive, inductive and mixed. Deductive is a learning strategy that starts from things that are general to specific items. Inductive is a learning strategy that starts from things that are specific to general. While the mixed strategy is a mixed learning strategy of deductive and inductive.

The Civic Education material approach uses the following approaches:

1. The values and morals of Pancasila are the basis for the delivery of Citizenship Education materials

2. Whole and continuous, which means that the program and the pattern of the teaching process must be able to foster: (1) the formation of the child's personality as a whole, namely the fostering and development of the child's cognitive, affective and psychomotor potential in high 
levels according to his development and ability. (2) fostering teaching materials as a whole and round and integrated with all aspects of student life.

3. Thematic, extensive and dimensional. In the sense that the obligation to develop teaching materials (1) for cognitive, affective, and psychomotor areas with high textomic levels (2) teaching materials must include data, facts, concepts, values, morals and norms in a clear and interconnected and continuous manner.

4. Student-centric and ecosystem. In the sense that the state of the level of development of student's abilities and meaning, teaching materials must be the basis of calculation, also constantly adapting to the circumstances and learning environment of students, society, country and the pace of development of science and technology, art and the rate of development.

The approach to presenting Civics Education materials is attempted to use a learning method that activates students as a learning principle that involves all students' potential in a balanced manner with relatively high levels for each domain. Planning a method that will be used in learning Civics Education, it is necessary to remember that a learning activity that will occur is not solely based on the will of the teacher but based on the needs of students in learning. Besides, it should be remembered that all methods are essentially good. There is no single method that is the best and most appropriate for certain subjects, including Citizenship Education. For this reason, the quality of the method that has been planned should be well understood and tried again and again. So that a set of data is obtained about the weaknesses and strengths of the method and then it can be used as a guide to modify it in the implementation of further learning.

The assignment method presents teaching materials by giving assignments to students or students to carry out a series of activities outside of face-to-face hours for material to be discussed at the next meeting. A series of assigned activities can take the form of; create clippings, wall magazines, summaries, summaries, completion of exercises and others. Giving assignments from the teacher is carried out either after the subject matter is presented or before the material is presented (initial assignment), the implementation is carried out both individually and in groups. Because assignments are carried out outside of face-toface hours, this method is often referred to as Homework (PR). By giving assignments for students, creativity and habits will grow to carry out a series of exercises and learning activities outside of face-to-face and acquire a series of knowledge and skills. The teacher cannot abandon this method because to master the entire scope of the material, and lessons cannot be limited to classroom learning. The 
initial assignment method is applied with the aim of:

1. To maintain student learning activities by discovering their potential outside of faceto-face hours so that the depth and breadth of lessons can be mastered

2. To overcome learning materials that are felt to be too full so that it is impossible to achieve if only based on the available time allocation. So by presenting the initial task, it can be achieved, especially learning materials that students can learn without going through face-to-face. Thus, the initial administration method has the following advantages:

3. Train students to expect activities to find their own learning experience and encourage a diligent, thorough, and creative attitude.

4. Motivate students to be better prepared with the material to be presented

5. Train students accustomed to independent study.

6. Encourage the development of students' attitudes and abilities in doing something difficult without the intervention of other parties.

7. Encourage students to self-assess how far their strengths and weaknesses are in doing the task.

Before the subject matter is taught, the provision of initial assignments has a procedure and prior planning set by the teacher in preparation for teaching. So all learning activities have been programmed in the lesson plan (RPP) both before the presentation, during the presentation of the lesson and after the presentation of the subject matter.

The steps for giving the initial assignment are:

1. Making preparations, among others (a) Formulating specific learning objectives (TPK), (b) Setting topics, prioritizing topics that will be raised from the subject/sub-subjects that are expected to be studied by students by reading sourcebooks, (c) Establish procedures for presenting lesson materials to support the achievement of specific learning objectives (TPK), and (d) Set time for completion of initial assignments.

2. Carrying out the Initial Assignment by (a) Informing the TPK to be achieved from giving the initial assignment at the end of the presentation of the material for the following material, (b) Explaining the topic that is the student's initial assignment, including its scope, (c) Informing the procedure for completing the assignment the beginning of the students, (d) Informing the completion time of the task, namely before the time for presenting the material the next day, (e) Giving the initial assignment in the form of questions that must be answered by students whose material is taken from the material to be discussed at the next meeting, and (f) Checking reports by providing reviews and 
necessary corrections about the students' initial assignments and then returning them to students.

\section{RESEARCH METHODS}

This research was an experimental study that examined differences in terms of student achievement that were taught by giving initial assignments before the subject matter was compared with the learning achievements of students who were not given initial assignments in the subject of Citizenship Education in class X for the 2019-2020 school year at State high school 4 Polewali.There were two variables in this study, namely the independent variable and the dependent variable. The variables in question were: Giving the initial assignment and without giving the initial assignment as the independent variable. Student achievement was the dependent variable.

In this research what is meant by:

1. The initial task is the task given by the teacher to the student/student before the subject matter is presented. This initial assignment is given at the end of the previous lesson, and the material is taken from the material that will be discussed at the next meeting. So the material is material that has not been discussed/explained but will be discussed at the next meeting.

2. Learning achievement is the highest value or result achieved by students after going through a teaching and learning process, which is expressed in numbers such as $5,6,7,8,9$ and so on.

This research was conducted for four months, starting from July to October 2019, at State high school 4 Polewali,Polman Regency. The population in this study was class $\mathrm{X}$ students for the 2019-2020 academic years, as many as four classes with 160 students.

While the samples in this study were taken two classes as research samples, this sample was determined using a random method, and 36 people were selected for class $\mathrm{X} .1$ as the control class and class X.4 with 36 people as the experimental class with a total of 72 people.

The instrument used was an achievement test sheet in the form of a description test. This test was carried out to determine whether there was a difference in student achievement, which was taught by being given assignments before the subject matter was discussed. The learning achievement of students who were taught without giving assignments before the subject matter was concerned. The description test consisted of 24 items tested four times in each class, class X.1 as a control and class X.4 as an experimental class after the learning activities were completed.

To collect data used test and documentation techniques. The test given is a descriptive test of 24 items in Citizenship Education for the four essential competencies. To obtain the necessary data, a test of learning 
outcomes was held on the subject of Citizenship Education, both students of class X.1 as a control class who were taught by giving initial assignments first and class X.4 students who were taught without giving initial assignments first as an experimental class.

The material (material) taught is the same in the control class and the experimental class, and the test, The results obtained in the form of scores of students' ability to complete the test.

\section{DISCUSSION}

Based on data analysis, there are differences in the learning achievement of class $\mathrm{X}$ students who are taught by giving initial assignments and the learning achievements of students who are taught without giving initial assignments in the subject of Citizenship Education at State high school 4 Polewali, Polman district. This illustrates that teaching in Citizenship Education subjects considered boring if preceded by giving an initial assignment before the material is presented will be more effective because students will be motivated and arouse interest in reading to find answers to the initial assignment. Besides, students will be challenged to get a solution from the initial task, which in the end, with increasing interest in reading, student achievement will increase. From the results of data analysis, it is proven that the learning achievement of students who are taught by being given an initial assignment has a higher learning achievement, namely an average of 7.81, and the learning achievement of students who are not given an initial assignment is an average of 7.07 or in other words that achievement students who are taught by giving the initial assignment are higher than the learning achievement of students who are not given the initial assignment first.

The increased learning achievement of students who were given initial assignments on Citizenship Education class $\mathrm{X}$ State high school 4 Polewali was due to students having prior knowledge of the material to be presented at the next meeting. This means that students are more ready to learn to discuss the material given through the initial assignment. For teachers, giving this initial assignment is very helpful because students first analyze and recognize the problem. The teacher functions as a facilitator and guides students in discussing the material in question. What is equally important is that by giving this initial assignment, students can learn more than playing outside the home.

\section{CONCLUSION}

Based on the results of the study, it can be concluded (1). that there is a difference between the achievements of students who are taught by giving initial assignments and the achievements of students who are taught without giving initial assignments to class $\mathrm{X}$ students for the 2019-2020 school year in the 
subject of Citizenship Education at State high school 4 Polewali.

(2). The average learning achievement of students who are taught by giving initial assignments for class $\mathrm{X}$ for the 2019-2020 academic year in Citizenship Education is 7.81 (3). (3). The average learning achievement of students who are taught without giving an initial assignment for class $\mathrm{X}$ for the 2019 2020 academic year in the subject of Citizenship Education is 7.07

\section{REFERENCES}

[1] Abd. Halim. Muharram. (1990) Pengaruh keterlibatan anak dalam membantu orang tua terhadap prestasi di SMA. Ujung Pandang IKIP.

[2] Sewang, A., \& Mustafa, T. (2020). Peningkatan Teacher Skills melalui Supervisi Klinis dengan Pendekatan Kooperatif Learning. Indonesian Journal of Educational Science (IJES), 3(1), 49-68.

[3] Bona Frans. (1986). Cara Belajar Efisien. Yokyakarta : Gajah mada. Universitas Press.

[4] Hadari Nawawi. (1989). Organisasi Sekolah dan Pengelolaan Kelas. Jakarta: Haji Masagung.

[5] Hartono,dkk (1993), Landasan dan Program Pengembangan Kurikulum Pendidikan Dasar.Jakarta:Depdikbud.

[6] Ivor K. Davies; terj. Sudarsono, (1991), Pengelolaan belajar,Jakarta, Rajawali Pers

[7] Muhammad Ali . (1983) Guru Dalam Proses Belajar Mengajar. Bumi siliwangi : Sinar Baru Algensindo.

[8] Mudhoffir. (1990). Teknologi Instruksional.Ediai Refisi. Bandung: Remaja Rosda Karya.

[9] Mustapa, T. (2017). Meningkatkan Hasil Belajar PKN Melalui Penerapan Model
Pembelajaran Kooperatif Tipe Think Pair Share (Tps) Pada Siswa Kelas X SMA Negeri 4 Polewali Kab. Polewali Mandar. JPPI (Jurnal Pendidikan Islam Pendekatan Interdisipliner), 1(1), 47-57.

[10] Mustapa, T. Influence of Individual Characteristics, Self Leadership, Peer Support and Working Pressure on Work Behavior and Performance of Teachers.

[11] Slameto, (1991). Belajar dan Faktor-Faktor yang Mempengaruhinya. Jakarta: Rineka Cipta.

[12] Soetinah Soewondo, (1980). Audio Visual Aids : Ujung Pandang IKIP.

[13] Suharsimi Arikunto. (1993). Media Pengajaran. Bandung : CV sinar Baru

[14] Suherman. (1992). Strategi Belajar Mengajar. Jakarta : PT Rineka Cipta

[15] Sutrisno Hadi. (2000) Statistik II. Yogyakarta: Andi Off set.

[16] Tutu, Mustapa. (2019). Meningkatkan Hasil Belajar Pendidikan Kewarganegaraan Melalui Penerapan Model Pembelajaran Kooperatif Tipe Think Pair Share Siswa Sekolah Menengah Atas Negeri 4 Polewali Mandar Provinsi Sulawesi Barat. JED (Journal of Etika Demokrasi), 4(2).

[17] W. J. S. Poerwadarminta. (1983). Kamus Umum Bahasa Indonesia. Jakarta : Balai Pustaka.

[18] Winarno Surakhmad. (1985). Pengatar Penelitian Ilmiah. Bandung : Tarsito. 